\title{
Geology and Occurrence of Gems in Sri Lanka*
}

\author{
J. W. Herath
}

Oceanography Unit, National Aquatic Resources Agency, Colombo 15, Srl Lanka

(Date of receipt: 17 August 1984)

(Date of acceptance: 28 December 1984)

\begin{abstract}
The gemstones of Sri Lanka with the exception of moonstones, some tourmaline, and garnets which have been found in situ, are all obtained from old alluvial deposits. Although the occurrence of gems in their rock-matrix is rare, there is no doubt that they are associated with some form of intrusive material and most probably originated in material of pegmatitic nature. The succession of formations observed in alluvial gem fields varies much in character according to the materials and the circumstances under which they are deposited. Perhaps nowhere in the world are so many minerals of the gem variety (common and rare) concentrated in such a comparatively restricted area of mountainous country as in the Sabaragamuwa Province of Sri Lanka in which Ratnapura is the main gem trading centre.
\end{abstract}

\section{Introduction}

Sri Lanka has long been renowned for its gems. In the Chronicles, reference is made to gems being brought from Ceylon to the Court of Solomon. The "Mahawansa' the great historical record of the Island, refers to the singular reputation of the Island for its gems. Several Greek writers of the first and second centuries refer to the reputation of Sri Lanka for its precious stones. From about the fourth century to the eleventh century the Arabs and the Persians exercised a great influence over the trade of the Island. The Venetian traveller, Marco Polo in the thirteenth century visited Sri Lanka on his homeward journey from China and in his book he mentions the gems of the Island. He also records that he found the Moors, the descendants of the Arabs, in undisputed possession of the gem trade of Sri Lanka. It is also believed that Sinbad's Valley of Gems in the Arabian Nights is probably the Ratnapura gem fields. Sri Lanka has therefore been famous for its gems since early historic times.

Sri Lanka is a tropical Island and lies $32 \mathrm{~km}$ to the east of the southernmost extremity of Peninsular India. It has an area of $65,600 \mathrm{sq} . \mathrm{km}$ and is $432 \mathrm{~km}$ long and $224 \mathrm{~km}$ at its greatest breadth. The Island may be divided into two main physiographic divisions:

1. The low lying coastal plain with little relief is traversed by rivers which have reached their base level of erosion.

2. The central highlands with immature drainage pattern and marked relief abounds in numerous strike ridges, hills and mountains.

\footnotetext{
* Paper read at the 19th International Gemmological Conference - Sri Lanka 1983
} 
The coastal plain is narrow in the western and southern parts of the Island. The general level varies from sea level to about $150 \mathrm{~m}$ where some erosion remnants rise to $300 \mathrm{~m}$ or more above sea level. The central highlands rise steeply from the coastal plain and the highest mountain (Pidurutalagala) attains an elevation of $2528 \mathrm{~m}$ above sea level.

Sri Lanka lies in the monsoon region of south-east Asia and it has a humid tropical climate. The division into a West Zone and Dry Zone which merge in an Intermediate Zone is one of the most conspicuous geographical features of the Island. In Figure 1 the rainfall pattern is shown clearly demarcating the Wet and Dry Zone. The average rainfall varies from below 50 inches $(1270 \mathrm{~mm})$ in the north-west and south-east parts of the lowland zone to over 200 inches $(5080 \mathrm{~mm})$ in the south-west slopes of the central hill country. The mean rainfall for the Island is 80 inches $(2032 \mathrm{~mm})$. In the Wet Zone area the average mean temperature varies between $21^{\circ}$ and $29^{\circ} \mathrm{C}$ and in the Dry Zone it may be nearer $32^{\circ} \mathrm{C}$. In the highlands the mean temperature ranges between $15^{\circ} \mathrm{C}$ and $26^{\circ} \mathrm{C}$ according to elevation.

The rivers are for the most part radial. The upper reaches are mainly confined to the hill country. The radial pattern is the dominant element in the drainage pattern in Sri Lanka. A great problem in the Wet Zone is flood control. In the Dry Zone a seasonal shortage of water is a problem. Very few rivers rise in the Wet Zone and flow into the Dry Zone. The main population concentration is in the Wet Zone. In the Dry Zone the population is sparse. The population of Sri Lanka is around 15 million.

The present paper attempts to give a broad picture of the geology, occurrence, origin and mining of gems in Sri Lanka. During the course of geological mapping of the Ratnapura, Rakwana and Balangoda areas (the main gem bearing areas of Sri Lanka), the author has had the opportunity of examining a large number of gem pits and was closely associated with the work of many gem-miners in the region. During this period of 2 to 3 years a considerable amount of useful information was gathered on the occurrence of gems. Although this paper is not an exhaustive treatment of the subject it provides in a convenient form a useful summary for those interested in the gems of the Island.

\section{General Geology}

Over 90 per cent of the surface area of the Island is underlain by Precambrian rocks: consisting of a complex series of high-grade metamorphic rocks, most of which have been derived from sediments and altered by one or more metamorphisms. Associated with these metamorphic rocks are granites and granitoid rocks of igneous. origin. Figure 2 shows the outcrops of the main geological formations in the Island and Table $I$ is presented to show the general succession of geological formations and the important mineral deposits of Sri Lanka. 


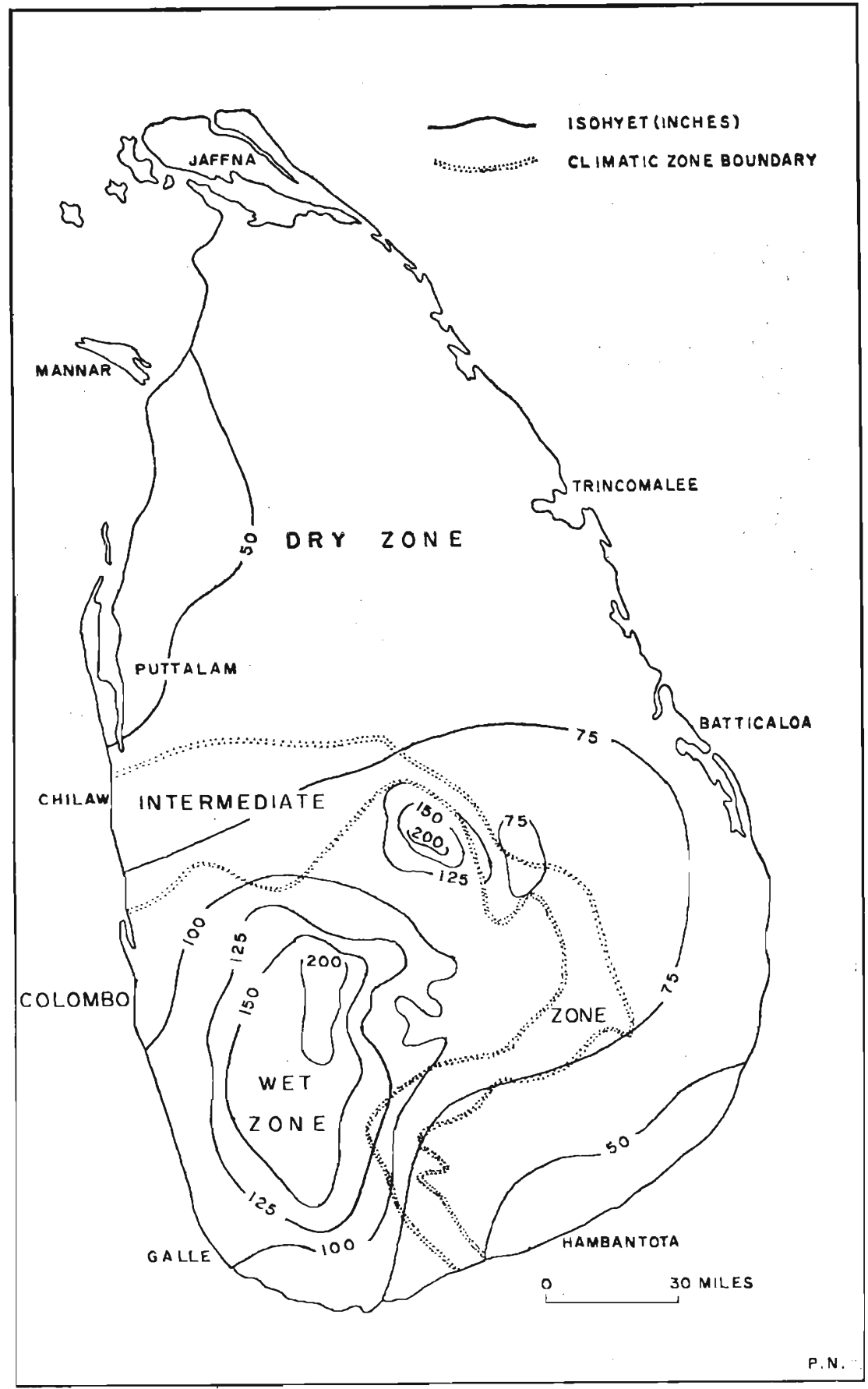

Frgure 1 - Rainfall Pattern - Sri Lanka 


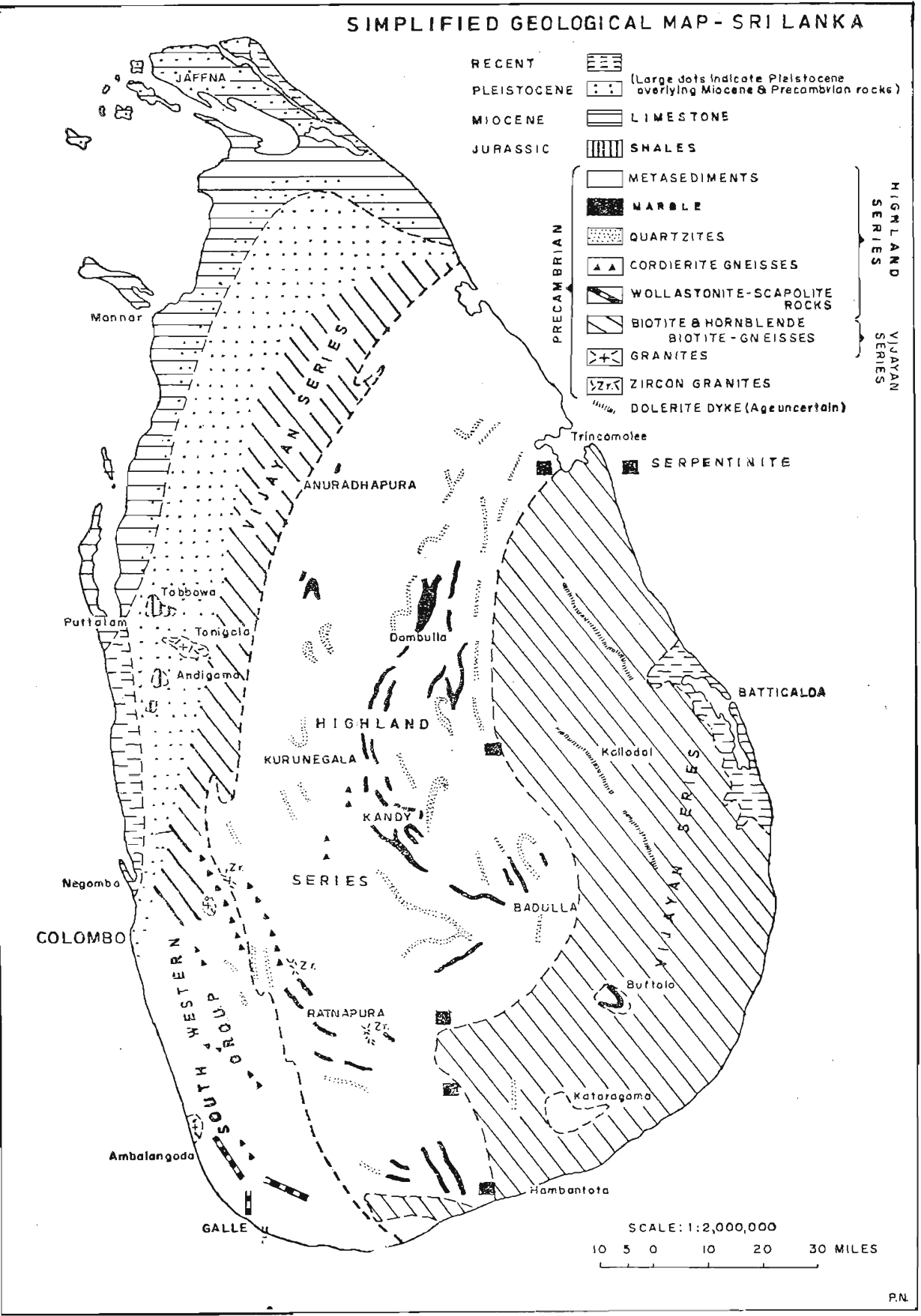

Frgure 2 - Simplified Geological Map - Sri Lanka 


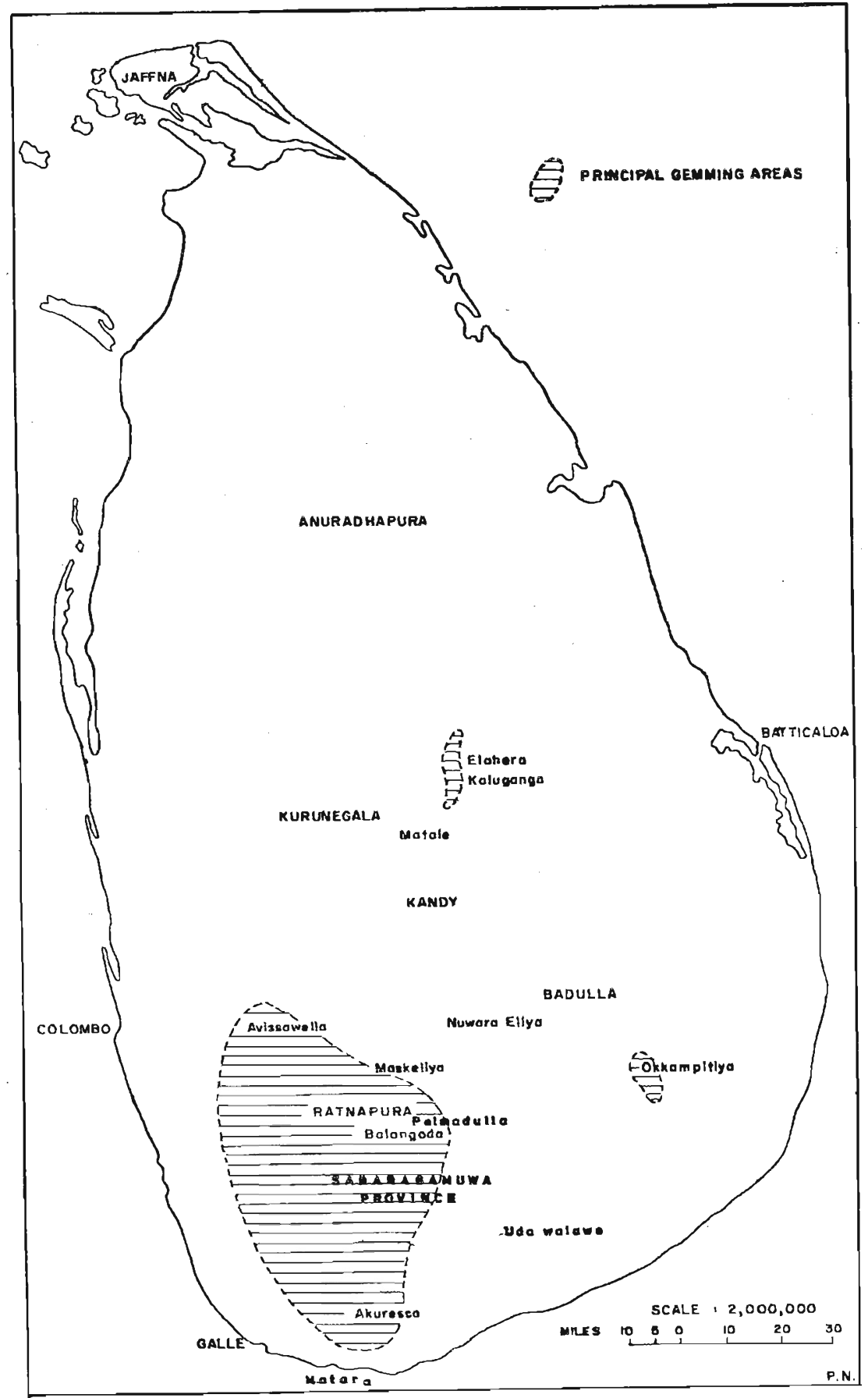

Figure 3 - Distribution of Gem bearing Gravel - Sri Lanka 


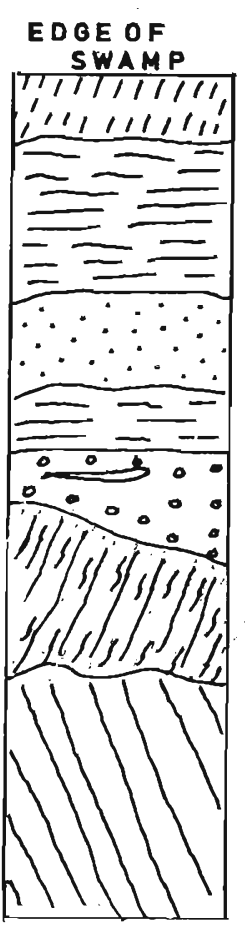

CROSS
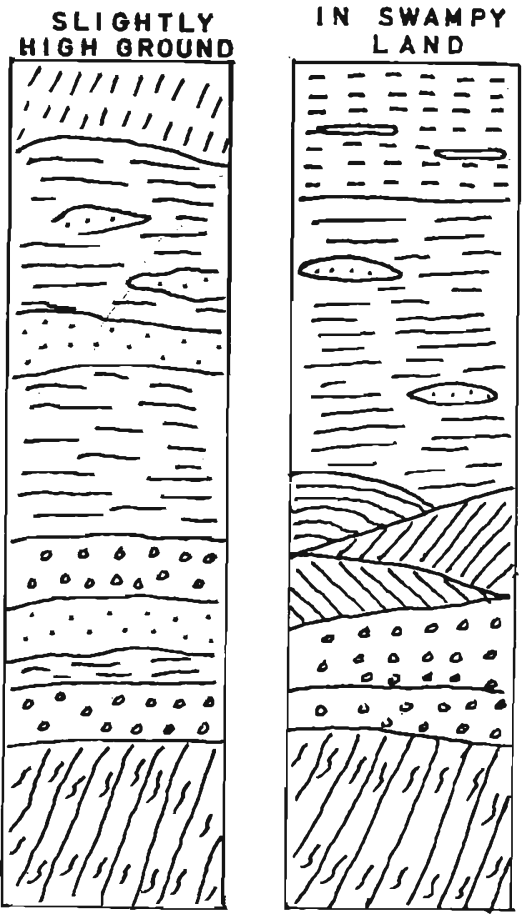

IN ALLUVIAL

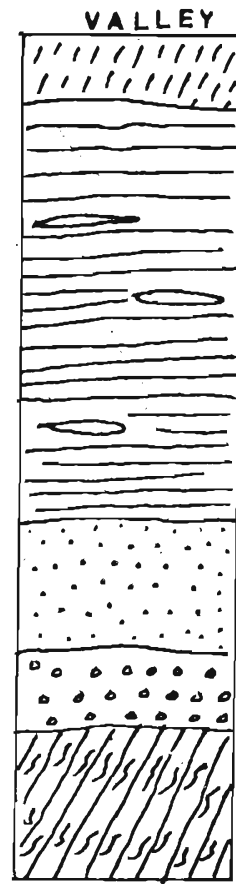

OF GEM PITS

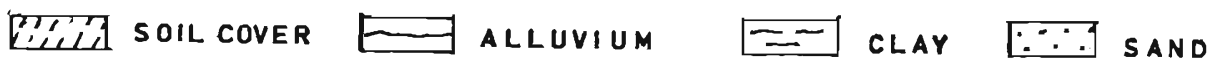

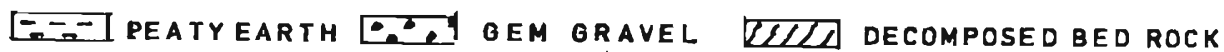
DIIV BED ROCK FALSE BEDDING SANDYCLAY

\begin{tabular}{cll} 
OVER BURDEN & OEM BEARING GRAVEL \\
$1-12 M$ & FEW CMS.TOIM THICK & FERNANDOIOG5 \\
\hline
\end{tabular}

Figure 4 - Succession of Formations in Gem Pits 


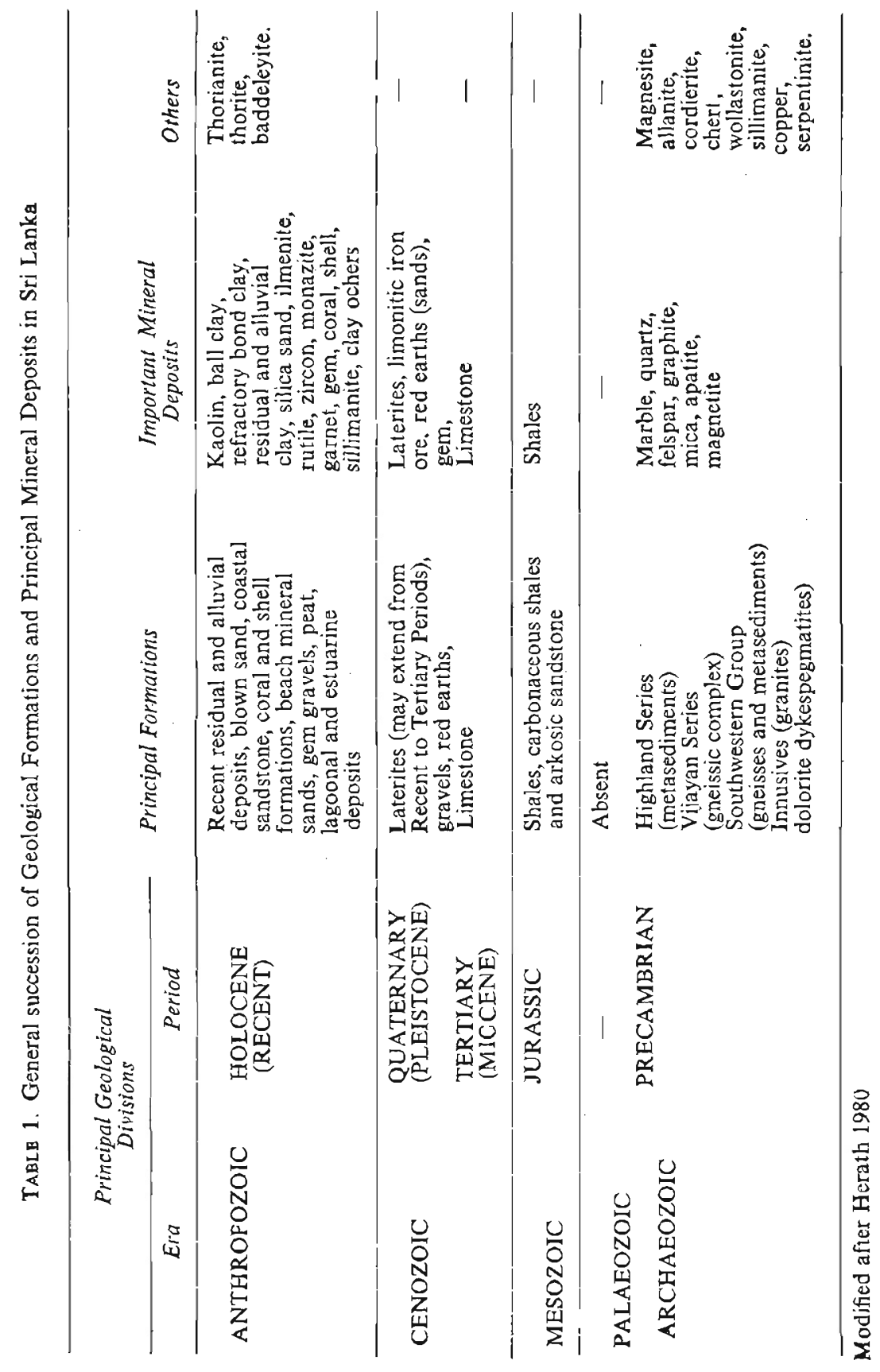


The precambrian crystalline rocks consist essentially of (1) a Highland Series (2) Vijayan Series and (3) the South - Western Group. The Highland Series is characterised by metamorphosed sediments and charnockitic rocks. The main rock types exposed are quartzites, marble (mainly dolomitic limestones), garnet-sillimanite-graphite schists, granulites and gneisses of various types including a variety of charnockitic rocks. The Vijayan Series is mainly composed of granites, gneisses of various types and migmatites. Athough the South - Western Group is fairly similar to the Highland Series there are differences between the two units in terms of both lithology and metamorphic character. Rock types in this group include thin quartzites, wollastonite bearing rocks, cordierite bearing gneisses, coarse charnockitic rocks and appreciable amounts of chert.

These rocks have been folded into a series of synforms and antiforms, generally trending in a north-west south-east direction. A good deal of controversy still remains about the subdivision of the Sri Lanka Precambrian, what can be generally agreed however, is that the structures are cverywhere complex. In recent years the boundary between the Highland Series and the eastern Vijayan has been recognized as a mineralized zone. A number of serpentinite rocks have been located on this boundary (Figure 2) and the Seruwila copper-magnetite deposit in the Trincomalee area is also confined to this zone.

The largest development of sedimentary rocks occur in the north-western coastal belt extending from the Jaffna Peninsula in the north to the south of Puttalam on the west coast. This formation is of Miocene age and the rock type is a massive limestone of marine origin which is fossiliferous. Jurassic rocks are limited in extent and they are exposed in the Tabbowa, Andigama and Pallama areas north of Chilaw. These sedimentary rocks are composed of sandstone, grits, arkoses and shales. Similar Jurassic (Gondwana) rocks occur below the Miocene limestone of the Mannar area (Petroleum surveys-drill cores).

Recent formations include a variety of unconsolidated materials (beach sands and extensive deposits of alluvial clays), coastal sandstone, coral and shell formations. The Pleistocene deposits include the gem gravels of the Island, red earths and ordinary gravel beds in the western and north-western parts of the Island and the laterite deposits in the south-western parts of the Island (residual deposits).

\section{Distribution and Geological Occurrence of Gems}

The main gem bearing area of Sri Lanka which has been known for centuries comprises a series of parallel hill ranges separated by longitudinal valleys and situated in the Sabaragamuwa Province. 
To date, the main gemming fields in the Island are confined to this area which covers nearly 1500 sq. km. The neighbourhood of Avissawella, Ratnapura, Rakwana and Balangoda has undoubtedly supported the most actively worked gem pits in the Island for a number of decades. This region has supplied to the market some high-priced blue sapphires, star sapphires and cat's eyes. Ratnapura (city of gems) is the main centre for the gem industry. Outside this area there are isolated gemming grounds of which Okkampitiya and Elahera are noteworthy. Other areas, include Nuwara Eliya, Horton Plains, Hatton, Kandy, Matara, Hambantota, Uda Walawe and many other localities underlain by Precambrian rocks.

The precious stones of Sri Lanka with the exception of moonstone (Meetiyagoda) corundum, and some tourmalines and a few garnets which have been found in situ are all obtained from old alluvial deposits. They represent the indestructible residual debris brought down from the high ground as products of degradation of the rocks and are found embedded in gravel layers and sand in beds of ancient rivers, in valley bottoms, beds of abandoned tributaries, alluvial terraces and in talus accumulations at the foot of hills. All gem minerals are undoubtedly from the rocks of the country in the vicinity of which they are found provided they have not been transported for great distances. Figure 3 is presented to show the distribution of gem bearing gravels in the Island. These are the better known areas but it is believed that gems have been found in many other parts of the Island in Precambrian terrain.

The succession of formations observed in the gem fields differ according to the circumstances and the type of material deposited in flood plains, wide flat bottomed valleys, residual gravel on hill slopes, fan type gravel occurrences at foot hills and gravel stretches on abandoned hill streams. Gravel formations with gem material have also been observed in decomposed material overlying concealed pegmatite dykes. The succession of formations in a typical gem pit may be classified into three categories: (Figure 4).

(i) Superficial layers of soil either lateritic or peaty overlying sandy and clayey material. The clayey material is in parts kaolinized. The thickness of this formation which is virtually the overburden varies considerably and is in general from 1 metre to 12 metres thick.

(ii) A layer or layers of pay-gravel usually of lenticular shape. This is the gem bearing gravel. The miner refers to it as the 'illam'. The illam layer is from a few cms to about a metre in thickness and may be encountered at shallow depths ( $<3$ metres) or at depths up to 12 metres.

(iii) The next formation is the decomposed rock which is normally kaolinized and micaceous. The decomposed material is termed the 'Malawa' 
by miners. In pits where more than one 'illam' or pay-gravel is struck, it is the lower ones which are more prolific in gems. All gem pits should theoretically end work on striking the 'malawa' layer or decomposed rock.

Apart from their economic value as the carrier of the principal gems the 'illam' gravels are highly interesting from a petrological and mineralogical point of view. Once the gems are recovered after washing, the gravels are discarded. This discarded material is termed 'Nambuwa' by the miners and up to recent years very light coloured corundum (semi transparent) has been discarded. Corundum of this nature termed 'Geuda' is now heat treated to enhance its blue colour. The most abundant constituent of gem gravel is quartz in well rounded pebbles. The gem miner has come to regard these quartz pebbles as an infallible companion of gemstones in the field and is guided in his search for pay-gravel by this criterion. Besides quartz and the ornamental stones including a variety of rare gem minerals the gem gravel may also contain grains and crystals of the rare earth minerals compounds of thorium, uranium, cerium, yttrium, niobium, titanium, beryllium, zirconium and others. In regard to gems in the pay-gravel there is a notorious uncertainty and variation in the content of gems. Some pay-gravel may draw blanks while pits dug a few metres away may yield very high priced gems.

\section{Origin of Gems}

No detailed work has been attempted on the origin of gems in Sri Lanka. Adams ${ }^{1}$ considered that they are the constituents of the associated crystalline rocks. $\mathrm{Kat}^{6}$ states that the Ratnapura-type gem deposits are derived from cordierite gneisses and associated rocks. Wadia and Fernando ${ }^{7}$ and Coates ${ }^{2}$ advocated a pegmatitic origin for some of the gem varieties. Dahanayake ${ }^{3}$ considered that most of the gem varieties in the Ratnapura and Elehara areas are found associated with garnetiferous gneisses and skarn-type marble deposits and this confirms the author's findings when geological field mapping was carried out in the Ratnapura and Rakwana areas in the mid 1960s.

Zircon from Sri Lanka gem gravel has been dated (560 m. y.). This does not mean that the gem gravel formed during this period. Deraniyagalat studied a number of fossils embedded in the gem-gravels of the Ratnapura area and his work indicates a Pleistocene age for the majority of the Ratnapura gem gravels. Wadia and Fernando ${ }^{7}$ however, mentions that the gem gravels do not all belong to any one particular age as erosion of the particular rocks of the surrounding area proceeded continuously through each succeeding geological age. Although a few instances are known of raw gem-stones occurring in rocks, there is however, no doubt regarding the pegmatitic habitat of topaz, tourmaline, beryl, chrysoberyl, amethyst, sphene and zircon, but only a few gems have been extracted from this 
source. In several Ratnapura fields, gems are found under conditions which point to their being not far removed from the source of origin, but the deep mantle of decomposed material in which the rocks are buried precludes their being examined by pits or trenches. The majority of the rare-earth minerals that are known have likewise come to light from their association with gem gravels. Their habitats are also unknown. It is therefore logical to assume that weathering has exposed deeper parts of the mountain folds of the Island where mineralization has taken place. This is the result of millions of years of subaerial weathering of the highly folded landmass which must have been very different in appearance from what we see now. This weathering process in previous geological ages have exposed pegmatite veins and rocks containing a number of minerals of gem quality. These. outcrops of rock and pegmatite material have been subjected to renewed process of weathering through countless ages of time and the gradual sorting action of the water has resulted in the deposition in favourable sites of gem gravel and sands which have subsequently been sealed by a covering of alluvial deposits as in the Ratnapura valleys.

\section{Gem Mining in Sri Lanka}

The mining methods employed although primitive using only manual labour, are time honoured methods of ancient Sinhalese tradition. They involve little capital outlay and are quick and efficient. Three methods are used to recover the gems:

1. Placer mining

2. Gemming by pits

3. Gemming of river beds by dredging.

1. When the pay-gravel is in superficial soil deposits within about 2 metres of the ground surface, the land is worked by open cast mining after clearing the surface. The material obtained is sorted out and washed in the usual manner in running water or in improvised sluices.

2. When the overburden is of considerable depth the most common method is to sink pits. The size of the pit is normally 3 to 5 metres square, divided into 2 chambers by a partition, one for working and excavating the gravel and the other for de-watering the sump. Lateral drifts are also driven in all directions from the bottom of the shaft in some of the deeper pits. The gravel is washed in shallow baskets made of rattan or wicker.

Very few pits use mechanised contrivances, however, in recent years a high degree of mechanisation has been introduced at the various mines. 
This is the most popular method of gem mining in the Sabaragamuwa mining area.

3. Gemming in beds of rivers is less common and require the assistance of experienced dredgers. An obstruction is put up across a stream to increase the flow of water at a selected spot over its bed. Long handled showels up to 40 feet or more in length are employed by six to eight men to drag the river bed at a point upstream of the dam till the illam layer is exposed after some weeks work. The overburden is carried away by the agitated water and the coarse sand and gravel (illam) is raked up and allowed to collect in a low ridge. This partly sorted illam is then removed from the water in baskets to the bank of the stream and the usual process of gem washing completed.

The gemming season normally extends from December to May, the drier part of the year. Under the existing mining law a licence to mine must be obtained from the State. No prospecting licences are issued for the search for gems. Applications for lease of gemming rights are on approval granted permits to mine for gems at an annual fee. Sometimes gemming rights are given after calling for tenders from applicants, a reserve price or upset premium is fixed beforehand. Seldom are gemming rights in Sri Lanka leased on a royalty or rent basis. The actual work of mining in the property is carried out on a remarkable system of co-operative sharing, of labour, expenses and profits. The output of the gem pit is distributed as follows:
Ground rent of owner
Lease or Licence-holder's share
Financier's share
Diggers share

20 per cent
10 per cent
35 per cent
35 per cent

Suppliers of the pump and timber may also be given a percentage share. This system of sharing is unique in a highly uncertain business. It has maintained the gem-cutting industry in a healthy state for centuries and has checked over production. The system of tenure under which land is held in Sri Lanka makes mechanical large scale operations unworkable in practice.

All mineral deposits that support mining are a constantly diminishing asset. This is true of the gem gravels of Sri Lanka. Exhaustion of gravels at a number of points is an indication that the Ratnapura gem beds will not be everlasting and that their extinction is only a question of time. New areas have however been found. In fact the entire Precambrian of Sri Lanka could be searched for gem gravel. Table 2 is presented to show the main gem varieties in the gem gravels of Sri Lanka and Table 3 is a list of the rare gem minerals of the Island as listed by Zoysa. ${ }^{8}$ 
Table 2. Sri Lanka Gem Varieties

\begin{tabular}{ll}
\hline Mineral & Gem Varieties \\
Corundum & $\begin{array}{l}\text { Star Sapphire ruby and star ruby, yellow, Blue, Green, Orange, } \\
\text { Pink and White Sapphire. }\end{array}$ \\
\hline Chrysoberyl & Alexandrite and Cat's Eye. \\
\hline Beryl & Aquamarine - Colourless, Pink, Yellow \\
\hline Topaz & $\begin{array}{l}\text { Colourless Yellow topaz. } \\
\text { Blue green and rarely red topaz (pale tints) }\end{array}$ \\
\hline Tourmaline & Black, pink, rose-red, blue, brown, green, varieties. \\
\hline GARNET & $\begin{array}{l}\text { Pyrope - deep red to black } \\
\text { Pyrope }\end{array}$ \\
Almandine & $\begin{array}{l}\text { Grosularite - honey yellow to brownish yellow, } \\
\text { also known as Hessonite or cinnamon stone }\end{array}$ \\
\hline Srossularite & Spinel - deep red, green, violet \\
\hline Zircon & Brown, Green, Blue, red, orange, and yellow varieties \\
\hline Quartz & $\begin{array}{l}\text { Rock crystal, amethyst, rose, quartz, smoky quartz, Citrine } \\
\text { (yellow) cat's eye quartz and star quartz }\end{array}$ \\
\hline Feldspar & Moonstone and amazon stone. \\
\hline
\end{tabular}

(After Herath 1980)

TABLE 3. Occurrence of rare Gem varieties in Sri Lanka

\begin{tabular}{lccc}
\hline Mineral & Star Varieties & Cat's Eye types & Colour change types \\
\hline Gamet & $-\mathrm{X}$ & - & $\mathrm{X}$ \\
Corundum & $\mathrm{X}$ & - & $\mathrm{X}$ \\
Spinel & $\mathrm{X}$ & - & $\mathrm{X}$ \\
Zircon & $\mathrm{X}$ & $\mathrm{X}$ & $\mathrm{X}$ \\
Andalusite & - & $\mathrm{X}$ & - \\
Apatite & - & $\mathrm{X}$ & - \\
Diopside & $\mathrm{X}$ & $\mathrm{X}$ & - \\
Enstatite & $\mathrm{X}$ & $\mathrm{X}$ & - \\
Euclase & - & $\mathrm{X}$ & - \\
Fibrolite & - & - & - \\
Ekanite & - & $\mathrm{X}$ & $\mathrm{X}$ \\
Kornerupine & - & $\mathrm{X}$ & - \\
Scapolite & - & & - \\
\hline
\end{tabular}

Other rare minerals present include morganite, Axinite, Danburite, Epidot, Iolite, Peridot Sinhalite, Sphene, Taaffeite. 
Gem cutting in Sri Lanka up to recent years was by machines of primitive construction operated by hand. No mechanical or electrical appliances were employed. During the past 5 to 7 years modern and up-to-date machinery has been introduced to the gem cutting industry and today machine cut gems of a very high quality could be obtained in the Island.

With a view to develop the gem industry of Sri Lanka, the State Gem Corporation was established in November, 1971. The Corporation now handles issue of permits for gemming, buys cut and uncut gems and all exports of gems from the Island have to be channelled through the Corporation. A modern gem testing laboratory with training facilities has been established and the Corporation has already made a significant contribution towards setting up a sound gem industry in the Island. In 1971 exports of gems from the Island were valued at Rupees 3,446,293 and in 1977 the export figures were in the region of Rupees 500 million and in 1982 exports were around Rupees 600 million. These figures indicate the increasing confidence owners of gems are beginning to have in the Corporation.

\section{Summary and Conclusions}

With the possible exception of Brazil no other country in the world produces such an abundance and variety of precious and semi-precious stones as Sri Lanka. The gemstones of the island are mainly obtained from old alluvial deposits and the main gem-bearing area is confined to the Sabaragamuwa Province of which Ratnapura is the Gem Trading Centre. Gems have however been found throughout the Precambrian of the Island. The co-operative system of working gem pits is unique in mining economics. In recent years mechanisation has been introduced in a number of gem mines and the gem cutting industry has also undergone changes. Machine cut gems of high quality are now freely available. Figures given for exports of gems cannot be considered as accurate as large quantities of gems are taken out of the country by illicit methods. Illicit mining is also prevalent in most parts of the Island. This activity has become so common that unconsidered action could result in a serious environmental problem.

Large scale gem mining operations using modern equipment cannot beundertaken in Sri Lanka and the present system of mining operations has maintained the industry in a healthy state for centuries, and has also checked over production. The possibility of expanding the jewellery industry has great promise. Regional Jewellery Centres could be established with adequate training facilities and such Centres could be operated by a State agency.

\section{Acknowledgements}

The author wishes to thank the State Gem Corporation, Gemmologists Association of Sri Lanka and Mr. T. G. Punchiappuhamy, former Chairman, State Gem Corpo- 
ration for inviting me to attend the 19th International Gemmological Conference Sri Lanka 1983. Valuable information has been obtained from the Geological Survey Department for the preparation of this paper. The paper is published with the kind permission of Dr. Hiran W. Jayewardene, Chairman - NARA.

\section{References}

1. Adams, F. D. (1929). The Geology of Ceylon, Canadian J. of Res. Vol. 1, Canada, 425-511.

2. Coates, J. S. (1935). Geology of Ceylon, Ceylon J. Sci. 19B, 101-187.

3. Dahanayake, K. (1980). Modes of Occurrence and Provenance of Gemstones of Sri Lanka, Mineral Deposita (Berl), 15, 81-86.

4. Deraniyagala, P. E. P. (1958). The Pleistocene of Ceylon, Ceylon National Museum Pub., Colombo - Sri Lanka.

5. Herath, J. W. (1980). The Mineral Resources of Sri Lanka, Eco. Bull., No. 2, Geological Survey Department, 60-63.

6. Katz, M. B. (1972). On the Origin of the Ratnapura-type Gem Deposits of Ceylon, Econ. Geol., 67, 113-115.

7. Wadia, D. N. \& Fernando, L. J. D. (1945). Gems and Semi-Precious Stones of Ceylon, Prof. Paper 2, Geological Survey Department, 1-44.

8. ZoysA, E. G. E. (1983). Unusual Gem Materials of Sri Lanka, (Abstracts), Symposium Geology of Sri Lanka, Peradeniya, 15. 